\title{
Co-Existence of a Large Ovarian Hemangioma and Microscopic Dysgerminoma in a 10-Year Old Child
}

\section{Yaşındaki Bir Çocukta Büyük Ovaryan Hemanjiyom ve Mikroskobik Disgerminom Birlikteliği}

\author{
Mehmet KEFELi' ${ }^{1}$, Filiz KARAGÖZZ' ${ }^{\text {, Anais MALPICA }}{ }^{2}$ \\ Department of Pathology, 'Ondokuz Mayıs University, Faculty of Medicine, SAMSUN, TURKEY, \\ ${ }^{2}$ MD Anderson Cancer Center, Section of Gynecologic Pathology, Houston, TEXAS, USA
}

\begin{abstract}
Ovarian hemangioma is an uncommon ovarian tumor occurring in patients in different age groups. It is usually seen as small, asymptomatic mass, which is detected incidentally. On rare occasions, this type of tumor can be associated with other gynecological neoplasms. In this report, we present the clinicopathologic features of a case of ovarian hemangioma coexisting with multiple microscopic foci of dysgerminoma in a 10 -year-old child. The patient presented with acute abdomen. Magnetic resonance imaging revealed a left ovarian mass and subsequent left salpingo-oophorectomy was performed. Grossly, the mass was $9.5 \mathrm{~cm}$ in diameter and contained hemorrhage and necrosis. Microscopic examination showed that the tumor was mostly composed of hemangioma. Additionally, there were three microscopic foci of dysgerminoma between the hemangioma and ovarian cortex. Immunohistochemical studies showed that dysgerminoma foci were positive for PLAP, Oct4 and CD117. To our knowledge, this is the first case of the above-described association ever reported.
\end{abstract}

Key Words: Ovary, Neoplasms, Hemangioma, Dysgerminoma, Childhood

\begin{abstract}
ÖZ
Ovaryan hemanjiyom farklı yaş gruplarındaki hastalarda ortaya çıkan nadir over tümörüdür. Genellikle rastlantısal olarak saptanan küçük, asemptomatik kitleler olarak görülür. Nadir durumlarda, bu tip tümörler diğer jinekolojik neoplaziler ile ilişkili olabilirler. Bu yazıda, 10 yaşındaki bir çocukta mikroskopik disgerminom odakları ile birlikte olan ovaryan hemanjiyom olgusunun klinikopatolojik bulguları sunuldu. Hasta akut karın yakınması ile hastaneye başvurdu. Manyetik rezonans görüntülemede sol overde kitle saptanması üzerine sol salpingo-ooferektomi yapıldı. Makroskopik olarak kitle 9,5 cm çapındaydı, kanama ve nekroz içeriyordu. Mikroskopik incelemede tümörün büyük kısmı hemanjiyomdan ibaretti. Ek olarak hemanjiyom ve ovaryan korteks arasında üç mikroskobik disgerminom odağı izlendi. İmmünohistokimyasal çalışmada disgerminom odakları PLAP, OCT-4 ve CD117 ile pozitifti. Bildiğimiz kadarıyla bu olgu yukarıda açıklanan birlikteliğe sahip, şimdiye kadar bildirilen ilk olgudur.
\end{abstract}

Anahtar Sözcükler: Over, Neoplasmlar, Hemanjiyom, Disgerminom, Çocukluk çağ 1

\section{INTRODUCTION}

Hemangiomas are benign vascular tumors that are found uncommonly in the gynecological tract. In the ovary, this type of tumor is usually detected incidentally. It is usually seen in children or young adults but it can occur in patients with a wide age range, from 4 months to 63 years. Although there is some controversy as to whether these represent hamartomas or true tumors, it is likely that both are responsible for their formation $(1,2)$.

Ovarian hemangiomas are usually under $1.5 \mathrm{~cm}$ in the largest dimension, and found asymptomatically. However, a few reported cases have presented with acute abdomen due to the large size of the neoplasm with secondary torsion

(Turk Patoloji Derg 2014, 30:210-214)

Received : 12.02.2013 Accepted : 15.03.2013
$(1,2)$. Seldom ovarian hemangioma may also be associated with other gynecological neoplasms. We present herein the clinicopathologic features of a case of ovarian hemangioma coexisting with multiple microscopic foci of dysgerminoma in a 10-year-old child who presented with abdominal pain. We also discuss the differential diagnosis of ovarian hemangioma with respect to their association with other gynecological tract neoplasms.

\section{CASE REPORT}

A 10-year-old girl was admitted to the hospital after one month history of abdominal pain. Blood tests and hormonal levels were within normal limits except placental alkaline phosphatase (596 U/L), which was slightly elevated (Normal

Correspondence: Mehmet KEFELİ

Ondokuz Mayıs Üniversitesi, Tip Fakültesi, Patoloji Anabilim Dalı,

SAMSUN, TURKEY

E-mail: mehmetkefeli@gmail.com Phone: +90 3623121919 
value $<300 \mathrm{U} / \mathrm{L}$ ). Magnetic resonance imaging (MRI) of the abdomen and pelvis showed a $9.8 \times 9.6 \times 7.4 \mathrm{~cm}$ left ovarian, solid mass with central necrosis and hemorrhage. These features prompted the imaging impression of a malignant mesenchymal tumor. A left salpingo-oophorectomy was subsequently performed.

Gross examination showed that the left ovarian mass measured $9.5 \times 6 \times 5.5 \mathrm{~cm}$. It was circumscribed and had an intact capsule (Figure 1). The tumor was tan-brown and contained small cysts, especially beneath the capsule, and it showed extensive necrosis and hemorrhage towards its center.

Microscopically, most of the tumor showed the histological features typically seen in a hemangioma (i.e., numerous thin-walled, large, vascular spaces lined by a single layer of bland endothelial cells and filled with red blood cells) (Figure 2). There were areas of hemorrhage and necrosis, especially in the center of the mass and the ovarian cortex was mostly obliterated. In addition, there were three foci of polyhedral cells with clear cytoplasm and prominent nuclei between the hemangioma and the thinned ovarian cortex (Figure 3). These cells were arranged in nests and cords separated by fibrovascular septae containing lymphocytes (Figure $4 \mathrm{~A}, \mathrm{~B}$ ) and they showed 1 to 2 mitoses per high power field. These foci measured at 0.2, 0.3, 0.8 $\mathrm{cm}$, respectively. Immunohistochemically, these cells were cytoplasmic positive for vimentin, placental alkaline phosphatase, CD-117 (Figure 5) and nuclear positive with Oct4 (Figure 6), but negative for cytokeratin, calretinin, inhibin, chromogranin A, synaptophysin, a-fetoprotein, S-100, CD 30 and desmin.

The final histological diagnoses were cavernoushemangioma and minute foci of dysgerminoma. No additional therapy

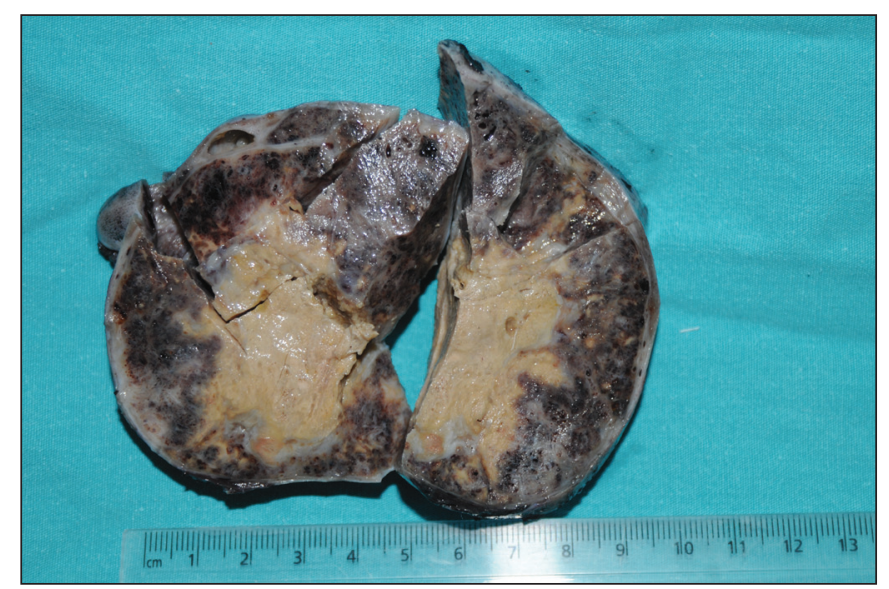

Figure 1: Gross appearance of the ovarian tumor, tan-brown in color and with extensive necrosis and hemorrhage in the center. was given and after a follow-up of 24 months the patient is alive with no evidence of disease.

\section{DISCUSSION}

Hemangiomas are benign vascular tumors that are rarely seen in the ovary. Less than 50 cases have been reported so far. They are usually small, under $1.5 \mathrm{~cm}$ in largest dimension and usually detected incidentally. However, a few reported cases have been associated with symptoms such as acute lower abdominal pain, massive ascites, elevated CA-125 and pleural effusion (pseudo-Meigs' syndrome) (2-5).

The ovary has very rich and complex vasculature in the medulla. Therefore it's not surprising that hemangiomas

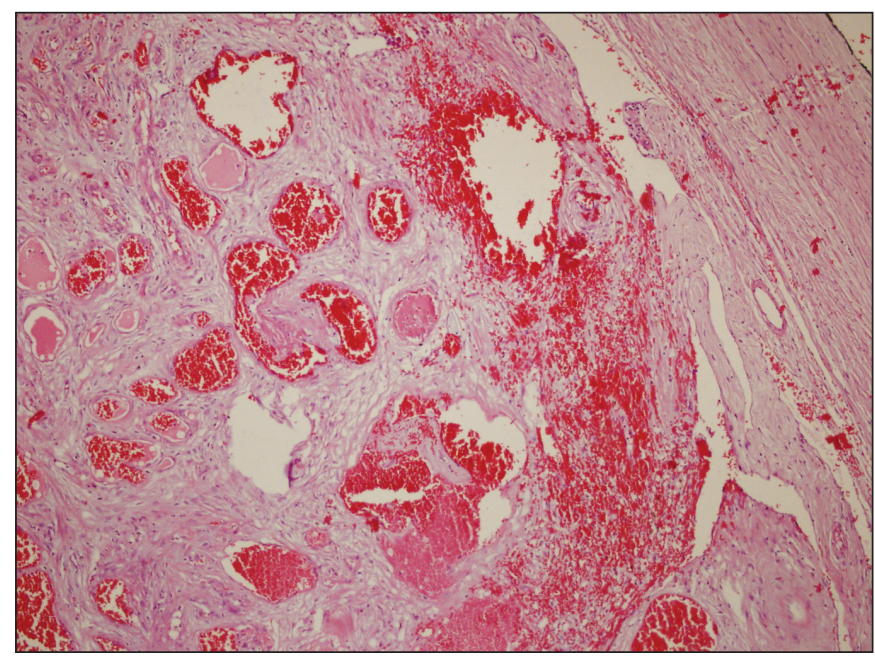

Figure 2: An ovarian hemangioma is characterized by numerous large calibers, thin-walled vascular spaces lined by a single layer of endothelial cells (H\&E, x100).

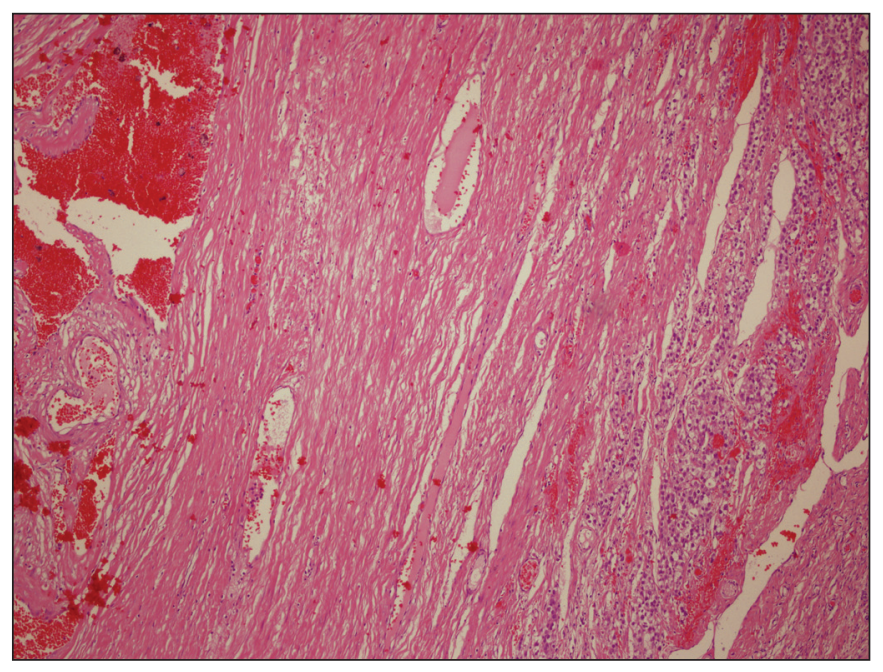

Figure 3: Hemangioma and dysgerminoma foci separated by fibrous capsule (Left side hemangioma, right side dysgerminoma) (H\&E, x100). 
are generally seen in the hilus or medulla and may be confused with normal vasculature. Various vascular tumors and their mimics have been reported in the ovary. Therefore, the differential diagnosis of ovarian hemangioma encompasses normal medullary vasculature, lymphangioma, hemangioendothelioma, angiosarcoma and the prominent vascular component of a teratoma. Since the ovarian medulla is rich of vascularized fibroelastic connective tissue, which may sometimes proliferate, the distinction between a small hemangioma and vascularized ovarian medulla can be challenging. To complicate this quandary, the normal blood vessels of the medulla can become numerous and closely packed in postmenopausal individuals. However, these vascular alterations are often small and more diffuse than hemangiomas and do not result in a distinct mass formation. Moreover, lymphatic vessels and nerve fibers are usually seen admixed with proliferated vessels in a vascularized medulla. Additionally, the ovarian medulla may have a few clusters of hilus cells which ovarian counterpart of testicular Leydig cells. They may seen between or around the proliferated vessels in medulla but not in hemangiomas. It is of note that these cells are only present during the fetal life and are not identifiable in childhood. However, they do reappear again at puberty and are demonstrable in all postmenopausal term $(2,6)$.

Ovarian lymphangiomas are also very rare and less than 20 cases have been reported so far $(1,7,8)$. Microscopically, they are characterized by the presence of thin-walled vascular structures, which are lined by flattened endothelial
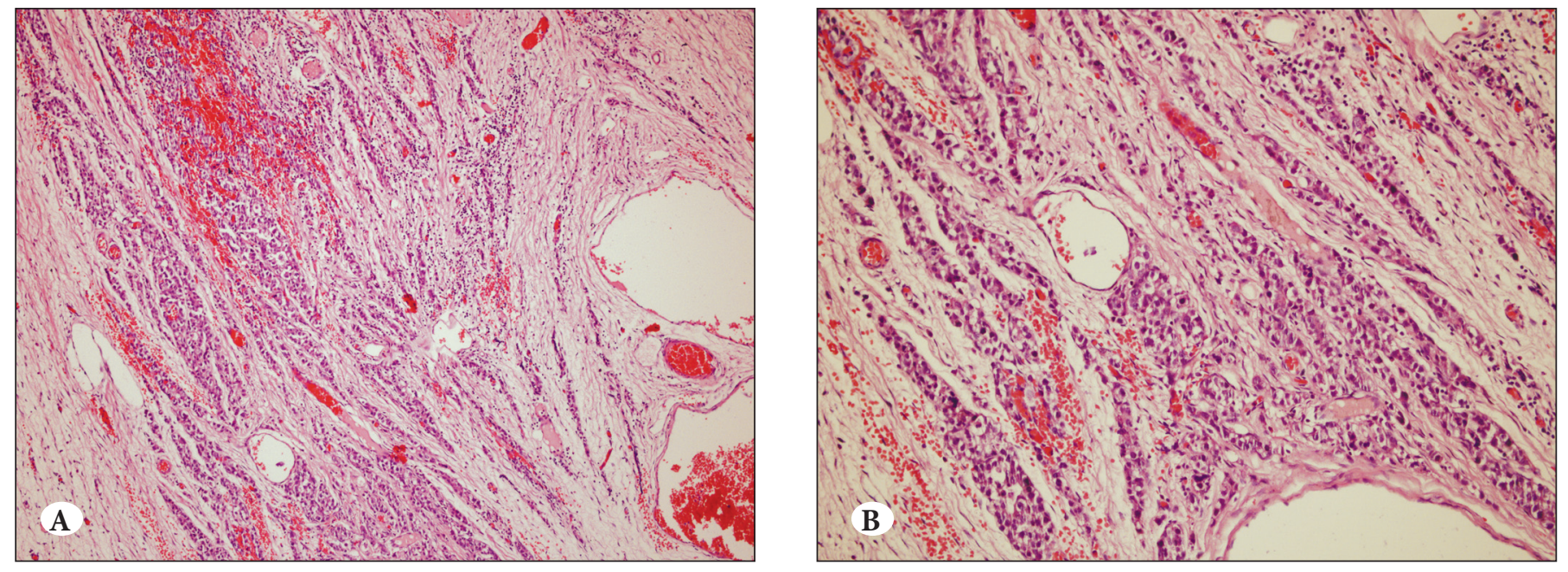

Figure 4A, B: Foci of dysgerminoma detected between the hemangioma and the ovarian cortex (H\&E, x100 and x200).

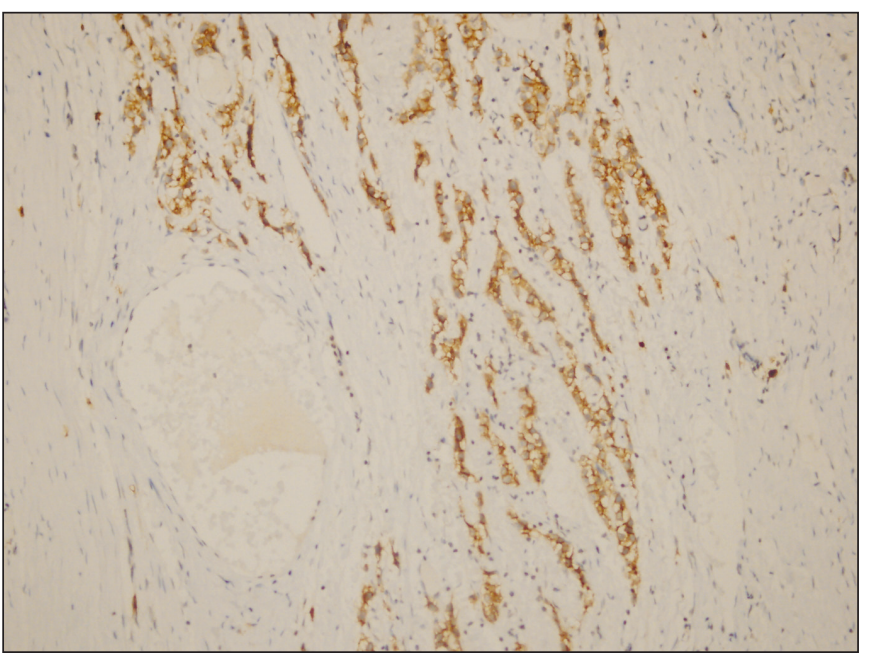

Figure 5: Dysgerminoma foci are positive for CD 117 immunostaining (DAB, x200).

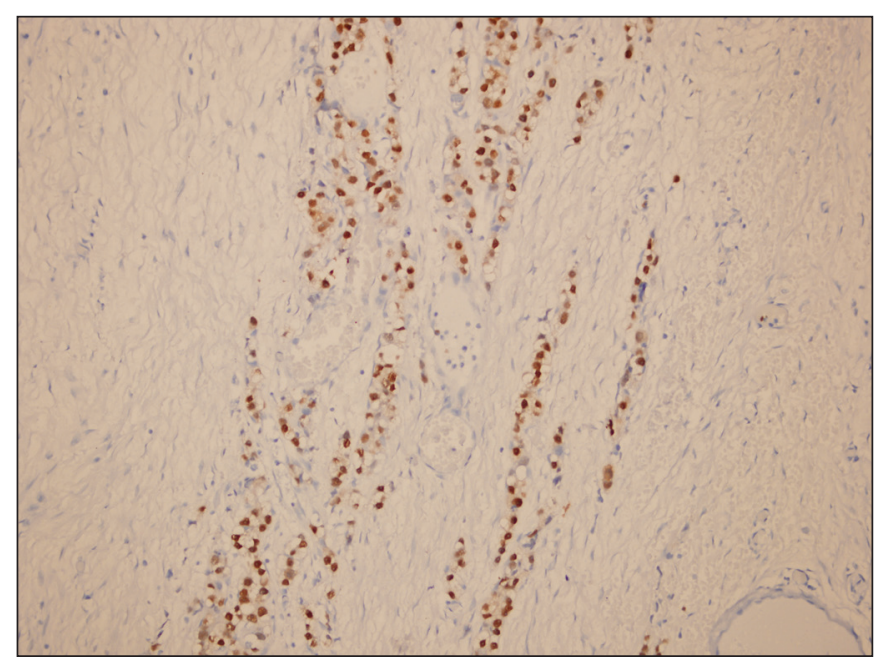

Figure 6: Nuclear Oct4 positivity in dysgerminoma cells (DAB, x200). 
cells and contain pale homogeneous eosinophilic fluid materials. Endothelial cells are positive for CD31 and D240 by immunohistochemically in lymphangiomas $(1,2)$.

Primary ovarian hemangioendotheliomas have been reported in three cases with different subtypes (kaposiform, infantile and epithelioid subtypes) (9-11). Two cases (kaposiform and infantile subtypes) have been reported in neonates, and the other case (epithelioid subtypes) has been reported in a 20 year-old patient. Microscopically tumors contained tightly packed, frequently dilated capillary blood vessels, which were lined with spindle cells, or plump, epithelioid cells depend to tumor subtypes. Those tumors had some cellular area, mild atypia and some mitosis but none of the mitosis atypical forms. Immunohistochemically, tumor cells were positive with vascular markers. In the presented case, vascular structures were thin-walled and large sized, and lined by a single layer of bland endothelial cells. However, no cellular areas, mitosis or other worrisome features are noted throughout the vascular component of this lesion.

Primary ovarian angiosarcomas are also rare neoplasms, less than 40 cases reported to date, and some of those have been associated with mature cystic teratoma (12). They are usually large and contain blue-brown, hemorrhagic and necrotic regions, which may be associated with an invasive growth into the adjacent structures. Microscopically, they display a variable size of vascular spaces lined by atypical endothelial cells that show increased mitotic activity including atypical mitotic figures as well as pleomorphism and papillary tufting. Hemangiomas do not have these nuclear features. Therefore their absence is important for the distinction of these entities $(1,2)$.

While benign and malignant vascular neoplasms can arise in the background of teratomas, florid reactive vascular proliferations mimicking hemangiomas were also reported in teratomas. These regions were usually accompanied with a neural tissue component. In those cases, the vascular structures can be variable; small to large vascular structures lined by oval to spindle shaped endothelial cells that exhibit mild atypia can be encountered in this context. Therefore, before making a diagnosis of hemangioma, adequate sampling is critical to distinguish it from a teratoma (13-15). We examined 35 samples from mass to make differential diagnosis of hemangioma and to determine for size of disgerminoma.

Ovarian hemangiomas rarely co-exist with other genital tract malignancies such as endometrial and ovarian carcinoma (16-18). We found only two cases of hemangioma associated with other ovarian tumors. The first case was that of a 32-year-old patient with ovarian hemangioma and mucinous cystadenoma (17). The second case was that of a 65-year-old with an ovarian serous carcinoma and an incidental small capillary hemangioma detected in the same ovary (18).

To our knowledge, this is the first reported case of a large ovarian hemangioma associated with foci of dysgerminoma. Although a large hemangioma is very unusual, it should be considered in the differential diagnosis of an ovarian mass and it may be coexisting with other ovarian tumors.

\section{REFERENCES}

1. Russel P, Roberts JM, Robboy SJ. Ovarian tumors: miscellaneous and metastatic. In Robboy SJ, Mutter GL, Prat J, Bentley RC, Russell P, Anderson MC. editors. Robboy's pathology of the female reproductive tract. 2nd ed. China: Churchill Livingstone Elsevier; 2009. 795-823.

2. Talerman A. Nonspecific tumors of the ovary, including mesenchymal tumors and malignant lymphoma. In Kurman RJ editors. Blaustein's Pathology of the female genital tract. 5th ed., New York:Springer Verlag; 2002. 1036-59.

3. Gehrig PA, Fowler WC Jr, Lininger RA. Ovarian capillary hemangioma presenting as an adnexal mass with massive ascites and elevated CA-125. Gynecol Oncol. 2000;76: 130-2.

4. Kaneta Y, Nishino R, Asaoka K, Toyoshima K, Ito K, Kitai H. Ovarian hemangioma presenting as pseudo-Meigs' syndrome with elevated CA125. J Obstet Gynaecol Res. 2003;29: 132-5.

5. Uppal S, Heller DS, Majmudar B. Ovarian hemangioma--report of three cases and review of the literature. Arch Gynecol Obstet. 2004;270:1-5.

6. Clement PB: Histology of the ovary. In Sternberg SS editor. Histology for pathologist. 2nd ed. Philadelphia:LippincottRaven; 1997. 929-56.

7. Iwasa T, Tani A, Miyatani Y, Bekku S, Yamashita M, Nakanishi $\mathrm{K}$, Fujii Y, Ino H. Lymphangioma of the ovary accompanied by chylous ascites. J Obstet Gynaecol Res. 2009;35: 812-5.

8. Evans A, Lytwyn A, Urbach G, Chapman W. Bilateral lymphangiomas of the ovary: An immunohistochemical characterization and review of the literature. Int J Gynecol Pathol. 1999;18: 87-90.

9. Thompson CV, Wells JM, Bowen C, Brundler MA, Kearns P, Arul GS. Intra-abdominal Kaposiform hemangioendothelioma and the benefits of laparoscopic surveillance. Pediatr Blood Cancer. 2012;58: 992-3.

10. Prus D, Rosenberg AE, Blumenfeld A, Udassin R, Ne'eman Z, Young RH, Ariel I. Infantile hemangioendothelioma of the ovary: A monodermal teratoma or a neoplasm of ovarian somatic cells? Am J Surg Pathol. 1997;21: 1231-5.

11. Illueca C, Machado I, García A, Covisa A, Morales J, Cruz J, Traves V, Almenar S. Uncommon vascular tumor of the ovary. Primary ovarian epithelioid hemangioendothelioma or vascular sarcomatous transformation in ovarian germ cell tumor? Arch Gynecol Obstet. 2011;284: 1589-91. 
12. Contreras AL, Malpica A. Angiosarcoma arising in mature cystic teratoma of the ovary: A case report and review of the literature. Int J Gynecol Pathol. 2009;28: 453-7.

13. Baker PM, Rosai J, Young RH. Ovarian teratomas with florid benign vascular proliferation: A distinctive finding associated with the neural component of teratomas that may be confused with a vascular neoplasm. Int J Gynecol Pathol. 2002;21: 16-21.

14. Itoh $H$, Wada $T$, Michikata $K$, Sato $Y$, Seguchi $T$, Akiyama Y, Kataoka H. Ovarian teratoma showing a predominant hemangiomatous element with stromal luteinization: Report of a case and review of the literature. Pathol Int. 2004;54: 279-83.

15. Feuerstein IM, Aronson BL, McCarthy EF. Bilateral ovarian cystic teratomata mimicking bilateral pure ovarian hemangiomata: Case report. Int J Gynecol Pathol. 1984;3: 393-7.
16. Gücer F, Ozyilmaz F, Balkanli-Kaplan P, Mülayim N, Aydin O. Ovarian hemangioma presenting with hyperandrogenism and endometrial cancer: A case report. Gynecol Oncol. 2004;94: 821-4.

17. Jurkovic I, Dudriková K, Böör A. Ovarian hemangioma. Cesk Patol. 1999;35: 133-5.

18. Akbulut M, Bir F, Colakoğlu N, Soysal ME, Düzcan SE. Ovarian hemangioma occurring synchronously with serous papillary carcinoma of the ovary and benign endometrial polyp. Ann Saudi Med. 2008;28: 128-31. 